\title{
Implications of Non-Performing Loans on the Nigerian Deposit Money Banks
}

\author{
Saliu Hakeem Tomi M.Sc \\ Department of Banking and Finance \\ Faculty of Management Sciences \\ Kogi State University \\ P.M.B I008, Anyigba, Kogi State, Nigeria \\ E-mail:tomisaliu@gmail.com \\ Idih Ogwu Emmanual $P h D$ \\ Department of Banking and Finance \\ Faculty of Management Sciences \\ Kogi State University \\ P.M.B I008, Anyigba, Kogi State, Nigeria \\ E-mail: emmiteI0I0@gmail.com \\ Adewole Joseph Adeyinka $P h D$ \\ Department of Banking and Finance \\ Faculty of Social and Management Sciences \\ Adekunle Ajasin University \\ P.M.B 00I, Akungba Akoko, Ondo State, Nigeria \\ E-mail: princeadeyinkaadewolej@gmail.com
}

\begin{abstract}
The study examined the arguments and counterarguments within the scientific discussion on the implications of non-performing loans on the Nigerian deposit money banks. The main objective is to examine the effect of Non-Performing loan on the Performance of Deposit Money Banks in Nigeria. Data were sourced from Central Bank of Nigeria Statistical Bulletin. A systematization literary approach for data analysis was Auto Regression distribution lag (ARDL) bound tests. Findings revealed that there exist a long run significant relationship between Non performing loan and the Performance of Deposit Money Banks in Nigeria. It was revealed that persistence increase in Non-performing loans results in poor Performance of Deposit Money Banks in Nigeria. It was also discovered that Non Performing Loan reduces deposit money banks return on asset. The study therefore recommends that deposit money banks should employ competent risk managers that always use their skills to reduce the incident of non-performing loans in the Nigerian deposit money banks. The study also recommends that deposit money banks in Nigeria should always monitor the end-use of funds given to their customers in order to curb the incident of fund diversion which may result in non-performing loan.
\end{abstract}

Keywords: Non-Performing Loan, Performance, Return on Assets, Economic Growth Rate, Credit Risk Management.

\section{Introduction}

The increasing documentations of non-payment of either loan principals or loan interest in at least 90 days are alarming and most responsible for financial sector problems experienced in Nigeria (Adeyemi, 20I I; Benji, 2013; Samayo, 2010). Hamisu (20II) posited that the banks and other economic industries drive and played key part in the socio-economic growth in the Nigeria Economy where they provide multiple economic supports that contribute positively to the survival of the Nigerian Economy. However, many banks in Nigeria today are making huge losses due to the problem of non-performing loans. Clearly, this is a negative impact against the banks' intermediate role in economic growth. The rate at which these organizations lend credit to companies and certain individuals increases the nation's economic growth rate (Kolapo, Ayeni, Oke, 20I2). Nigeria banking system is regulated and monitored by the bank of Nigeria with the Banking Act made by the parliament of Nigeria. The Acts has regulations which guide the activities of all banks and some other financial institutions in the country.

The main objective is to examine the effect of Non-Performing loan on the Performance of Deposit Money Bank in Nigeria. The specific objectives are to ascertain the existence of Long Run relationship between the Non-Performing Loan and Deposit Money Banks Performance in Nigeria, to find out the short run and Long run impact of Non-Performing Loan on 
Performance of Deposit Money Banks in Nigeria, to identify the speed of adjustment at which Deposit Money banks adjust to long run equilibrium as a result as a result of Change in Nonperforming Loan and to evaluate the proportion of variation of the Performance of Deposit Money bank explained by Non-Performing Loan.

The research questions formulated to guide the study are; what is the Long Run relationship between the NonPerforming Loan and Deposit Money Banks Performance in Nigeria? What is the short run and Long run impact of NonPerforming Loan on Performance of Deposit Money Banks in Nigeria? To what extent is the speed of adjustment at which Deposit Money banks adjust to long run equilibrium as a result of Change in Nonperforming Loan? What is the proportion of variation of the Performance of Deposit Money bank explained by Non-Performing Loan?

\section{Methodology}

This study employed time series secondary data covering the period from 1986 to 2018. Data was sourced from CBN Statistical Bulletin. The study adopted Auto Regression distribution lag (ARDL) bound tests to analyze the Long Run Relationship that exist between Non Performing Loan and DMB Performance in Nigeria while the Error Correction Model was used to evaluate the proportion of variation of the dependent variable explained by each of the independent variables. The Variance decomposition was adopted to capture the proportion of variation of the dependent variable explained by each of the independent variables while some diagnostic test was carried to test the reliability and predictability of the model.

\section{I Model Specification}

$\mathrm{ROA}=\mathrm{F}(\mathrm{NPL}, \mathrm{BDB}, \mathrm{BCR} \mathrm{ID}, \mathrm{TDB})$

$\mathrm{ROA}_{t}=\mathrm{B}_{0}+\mathrm{B}_{1} \ln N P L_{t}+\mathrm{B}_{2} \ln \mathrm{BCD}_{\mathrm{t}}+\mathrm{B}_{3} \ln \mathrm{TDB}_{\mathrm{t}}+\mathrm{B}_{4} \mathrm{BCRIDt}+\mathrm{U}_{\mathrm{t}}$

$\mathrm{bI}<0, \mathrm{~b} 2>0, \mathrm{~b} 3>0, \mathrm{~b} 4>0$ and $\mathrm{b} 5>0$.

$\mathrm{ROA}_{\mathrm{t}}=\mathrm{B}_{0}+\sum_{t=i}^{n} \mathrm{~B}_{\mathrm{I}} \operatorname{lnNPL}+\sum_{t=i}^{n} \mathrm{~B}_{2} \operatorname{lnBCD} \mathrm{t}_{\mathrm{t}}+\sum_{t=i}^{n} \mathrm{~B}_{3} \ln \mathrm{TDB}_{\mathrm{t}}+\sum_{t=i}^{n} \mathrm{~B}_{4} \mathrm{BCRID}_{\mathrm{t}}+\mathrm{U}_{\mathrm{t}}$

The estimated short-run equation and the error correction term are

$\mathrm{ROA}_{\mathrm{t}}=\mathrm{B}_{0}+\sum_{t=i}^{n} \mathrm{~B}_{\mathrm{I}} \operatorname{lnNPL} \mathrm{t}_{\mathrm{t}}+\sum_{t=i}^{n} \mathrm{~B}_{2} \operatorname{lnBCD}_{\mathrm{t}}+\sum_{t=i}^{n} \mathrm{~B}_{3} \ln \mathrm{TDB}_{\mathrm{t}}+\sum_{t=i}^{n} \mathrm{~B}_{4} \mathrm{BCRID}+\mathrm{ECM}_{\mathrm{t}=\mathrm{i}}+\mathrm{U}_{\mathrm{t}}$

Many authors have used similar method to explain the issue of non-performing loan; Mohammad, Ammara, Abrar and Fareeha (2012) examined economic determinants of non-performing loans using correlation and regression analysis to analyze the impact of selected independent variables and the result reveals that interest rate, energy crisis, unemployment, inflation and exchange rate has a significant positive relationship with the non-performing loans of Pakistan banking sector, while GDP growth rate has a significant negative relationship with the non-performing loans of Pakistan banking sector.

Bofondi and Ropele (20II) investigated the macroeconomic determinants of bad loans of Italian banks for the period I990-2010 using quarterly data and found that non-performing loans are positively associated with the unemployment rates, lending rates and negatively associated with the GDP growth rate. Similarly, Ekanayake and Azeez (20I5) viewed that the determinants of non-performing loans in certified commercial banks in Sri Lanka for the period 1999-2012 were explored and it was discovered that the level of non-performing loans can be attributed both to macroeconomic situations and to particular factors for banks. Results of their study reveal that non-performing loans tend to increase with deteriorating bank efficiency and a positive correlation between loan asset ratio and non-performing loans occurred. They also observed that banks with high credit growth rates are associated with lower levels of non-performing loans, while larger banks incur loan defaults that are lower than smaller banks. However, the study found with regards to the macro economic variables, that non-performing loans vary negatively with growth rate of GDP, while inflation was positively related to the prime lending rate.

3. Presentation of Data

\begin{tabular}{lccccc}
\hline & BCD & BCIR & NPL & ROA & TDP \\
\hline Mean & 84.01459 & $65.570 I 9$ & I4.5678I & 2.495662 & I2.46906 \\
\hline Median & 81.84000 & 66.15500 & I3.8I500 & 2.332251 & I0.25000 \\
\hline Maximum & $\mathrm{I} 06.7700$ & 81.37000 & 37.25000 & 4.120000 & 22.54000 \\
\hline Minimum & 61.22000 & 55.69000 & 2.120000 & 0.090000 & 6.070000 \\
\hline Std. Dev. & $\mathrm{I} 2.65723$ & 6.762784 & 9.647148 & 0.777410 & 4.976759 \\
\hline Skewness & 0.252767 & 0.270515 & 0.563522 & -0.366385 & 0.280608 \\
\hline
\end{tabular}




\begin{tabular}{lccccc}
\hline Kurtosis & $2.107 \mathrm{I} 24$ & $2.2206 \mathrm{I} 4$ & 2.678805 & 4.584726 & $\mathrm{I} .55 \mathrm{I} 357$ \\
\hline Jarque-Bera & $\mathrm{I} .403723$ & $\mathrm{I} .200207$ & $\mathrm{I} .831 \mathrm{I} 95$ & $4.0644 \mathrm{II}$ & 3.218038 \\
\hline Probability & 0.495662 & 0.548755 & 0.400277 & 0.131046 & 0.200084 \\
\hline Sum & 2688.467 & 2098.246 & 466.1700 & 79.86119 & 399.0100 \\
\hline Sum Sq. Dev. & $4966.37 \mathrm{I}$ & $\mathrm{I} 417.793$ & 2885.092 & 18.73536 & $767.8 \mathrm{I} 2 \mathrm{I}$ \\
\hline Observations & 32 & 32 & 32 & 32 & 32 \\
\hline
\end{tabular}

Source: Authors Computation E-view 9.0

The tables depicts the descriptive statistics of the variables A mean of $84 \%$ of the Bank deposit is granted as loan in which I4\% of such loan turn bad and non performing to achieve a Mean Return on asset of 2.49 The maximum NPL during the period is 37.25 while the Minimum NPL is 2.12. The NPL varies from its mean by a standard deviation of 9.64.

\section{I Stationary Test}

\begin{tabular}{lllllll}
\hline Variables & ADF & I\% & $5 \%$ & I0\% & Probability & Decision \\
& Statistics & & & & & \\
\hline LnROA & -5.181152 & -3.653730 & -2.957110 & -2.617434 & 0.0002 & $\mathrm{I}(0)$ \\
\hline LnNPL & -5.325477 & -3.724070 & -2.986225 & -2.632604 & 0.0001 & $\mathrm{I}(\mathrm{I})$ \\
\hline LnBCD & -3.208560 & -3.724070 & -2.986225 & -2.632604 & 0.0314 & $\mathrm{I}(\mathrm{I})$ \\
\hline LnTDP & -3.173502 & -3.724070 & -2.986225 & -2.632604 & 0.0317 & $\mathrm{I}(\mathrm{I})$ \\
\hline LnBCIR & -3.745093 & -3.653730 & -2.957110 & -2.617434 & 0.0080 & $\mathrm{I}(0)$ \\
\hline
\end{tabular}

Source: Authors Computation E-view 9.0

The result above shows the level of stationary of the different variables. The table shows that $\ln B C I R$ and $\ln R O A$ are stationary at levels while LnNPL, LnBCD and LnTDP are stationary at first difference. Since the variables are stationary at level and first difference we establish the presence of stationary and adopt the autoregressive distributed lag model (ARDL).

\subsection{ARDL Bound Test}

The F-statistics calculated for all underlined variables fall outside the critical bounds at the I and 5 percent levels of significance. The calculated F-statistic is higher than the upper bound critical value at $99 \%$ level of significance, so there is need to reject the null hypothesis which states that there is no cointegration, which suggests that the variables under consideration are cointegrated and they have the long-run relationship hence conclude that there exist the presence of long run relationship among NonPerforming Loan and the performance of Deposit Money Bank in Nigeria.

\begin{tabular}{lll}
\hline \multicolumn{2}{c}{ Null Hypothesis: No long-run relationships exist } \\
\hline Test Statistic & Value & $\mathrm{K}$ \\
\hline F-statistic & $8.58729 \mathrm{I}$ & 4 \\
\hline Critical Value Bounds & & \\
\hline Significance & I0 Bound & II Bound \\
\hline $\mathrm{I} 0 \%$ & 2.45 & 3.52 \\
\hline $5 \%$ & 2.86 & $4.0 \mathrm{I}$ \\
\hline $2.5 \%$ & 3.25 & 4.49 \\
\hline $\mathrm{I} \%$ & 3.74 & 5.06 \\
\hline
\end{tabular}

\section{Short run and Long Run Estimate}

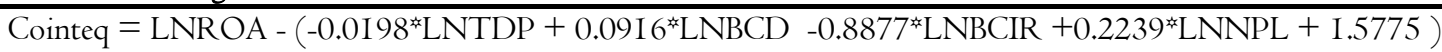

\begin{tabular}{rrrrr}
\hline \multicolumn{5}{c}{ Long Run Coefficients } \\
\hline Variable & Coefficient & Std. Error & t-Statistic & Prob. \\
\hline LNTDP & -0.019837 & 0.171690 & -0.1 I5543 & 0.9092 \\
\hline LNBCD & 0.091566 & 0.483005 & 0.189577 & 0.8516 \\
\hline LNBCIR & -0.887740 & 0.997051 & -0.890366 & 0.3839 \\
\hline
\end{tabular}




\begin{tabular}{cccrr}
\hline LNNPL & -0.223905 & 0.077448 & -2.891041 & 0.0090 \\
\hline C & $1.57745 \mathrm{I}$ & 2.177796 & 0.724334 & 0.4772 \\
\hline ECM & -1.776328 & 0.308669 & -5.754791 & 0.0000 \\
\hline
\end{tabular}

'The result above shows the long run estimate of the variables. The tables show that only Non-Performing Loan has significant effect on Bank Performance in the Long run. This might be due to the fact that the amount of nonperforming loan measures the quality of bank assets (Tseganesh, 2012). The effect of non-payment of due debts on banks ${ }^{\text {ee }}$ profitability can be identified with a possible bank failure, barrier to further lending, reduction in profit level and negative economic growth in the society. Hence a unit Percentage increase in Non-Performing Loan will lead to $22 \%$ reduction in the Return of Asset in the Long Run.

Short Run Coefficient Equation: Error Correction Model

\begin{tabular}{|c|c|c|c|}
\hline \multicolumn{4}{|c|}{ Short Run Coefficients } \\
\hline Variable & Coefficient & Std. Error & t-Statistic \\
\hline LNTDP & 0.024720 & 0.08119 & 0.30447 \\
\hline LNBCD & -0.010515 & 0.02432 & -0.4323 \\
\hline LNBCIR & -0.021908 & 0.04150 & -0.52797 \\
\hline LNNPL & -0.597 I I6 & 0.27759 & -2.15106 \\
\hline $\mathrm{C}$ & -0.009 & 0.03255 & -0.277 \\
\hline R-Squared $=0.47 \mathrm{I} 269$ & Adj. $R^{2}=0.233$ & $\begin{array}{ll}\text { Durbin } & \text { Watson }= \\
\text { I.84 } & \end{array}$ & \\
\hline
\end{tabular}

Source: Authors Computation from Eview 9.0

The short-run dynamics among the variables are explored by employing error correction mechanism (ECM). Error correction model explains the speed of adjustment in restoring the equilibrium in the dynamic model with a negative sign. Bannerjee, Dolado, and Mestre (1998) also observe that a significant ECM is evidence that a stable long-term relationship exists. Table above shows the result of ECM in terms of changes in Return on asset to change in other variables. The magnitude of the ECT coefficient of -I.77 at 5 percent level of significance shows that the speed of adjustment towards long-run equilibrium is very high, that is, there is $I 77$ percent increase over the previous year. The short run dynamics further affirm the long run relationship that Bank credit ratio to total deposit BCD, total financial system deposit and Bank cost to income Ratio has no significant impact on the return on asset in the short run also but only the Non-Performing Loan exhibited a negative significant impact on return on asset.

\section{Diagnostic Test}

\begin{tabular}{llll}
\hline \multicolumn{1}{c}{ Test } & \multicolumn{1}{c}{ F Statistics } & Probability \\
\hline $\begin{array}{l}\text { Breusch-Godfrey } \\
\text { test }\end{array}$ & serial correlation LM & 3.648037 & 0.00000 \\
\hline Heteroscedasticity(ARCH) & I7.34I2 & F I,28) 0.0096 \\
\hline $\begin{array}{l}\text { Heteroscedasticity(BreuschPagan- } \\
\text { Godfrey }\end{array}$ & 20.84385 & 0.0468 \\
\hline Normality Test (Jarque- Bera) & II7.58 & 0.00000 \\
\hline
\end{tabular}

Source: Authors Computation from Eview 9.0

Diagnostic tests such as Breusch- Godfrey serial correlation LM test, Breusch-Pagan-Godfrey Heteroskedasticity test and Jacque-Bera normality test. These tests show that there is no serial correlation, presence of homoscedastic and normal distribution. Hence, the model is line with the econometric properties and the results are suitable for reliable interpretation and policy implication.

\subsection{Impulse Response Function}

This describes the evolution of a model's variables in reaction to a shock in one or more variables. This feature allows tracing the transmission of a single shock within an otherwise noisy system of equations and, thus, makes them very useful tools in the assessment of economic policies. 


\section{Response to Cholesky One S.D. Innovations}

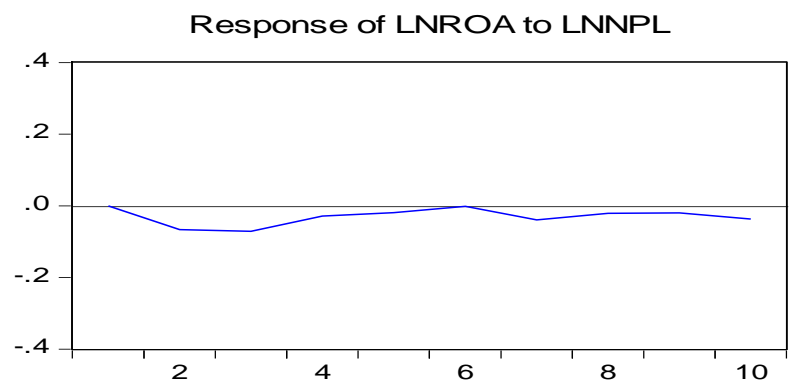

The result above shows the response of Return on Asset to innovation from Non-Performing Loan. This study shows that return on asset respond to Non-Performing Loan although the period and the responds is relatively uniform.

Variance Decomposition

\begin{tabular}{|c|c|c|c|c|c|c|}
\hline $\begin{array}{c}\text { VD of } \\
\text { LNROA: } \\
\text { Period }\end{array}$ & S.E. & LNROA & LNBCD & LNBCIR & LNTDP & LNNPL \\
\hline I & 0.313488 & 100.0000 & 0.000000 & 0.000000 & 0.000000 & 0.000000 \\
\hline 2 & 0.350966 & 86.27910 & $3.38623 \mathrm{I}$ & 0.998066 & 5.743668 & 3.592938 \\
\hline 3 & 0.436573 & 64.60282 & $4.20 \mathrm{I} 52 \mathrm{I}$ & 21.29085 & 4.921632 & 4.983175 \\
\hline 4 & 0.476380 & 63.69035 & $5.7528 \mathrm{I} 4$ & 20.40146 & 5.6 I I523 & 4.543850 \\
\hline 5 & 0.500836 & 65.45655 & 5.557380 & 4.253990 & 5.076896 & 4.253990 \\
\hline 6 & 0.524890 & 66.61772 & $6.2188 \mathrm{II}$ & 3.873575 & 4.625277 & 19.65519 \\
\hline 7 & 0.550445 & 66.46396 & 7.945937 & 4.027573 & 4.400085 & I8.66462 \\
\hline 8 & 0.575806 & 67.86450 & 8.331418 & 3.816965 & 4.026012 & I7.I6244 \\
\hline 9 & 0.595678 & 68.71249 & 8.552364 & 3.676716 & 3.768660 & I5.96IIO \\
\hline I0 & 0.617050 & 69.07802 & 9.030516 & 3.784593 & 3.512694 & I 5.28977 \\
\hline
\end{tabular}

Source: Authors Computation from Eview 9.0

The result of the variance decomposition above shows that total financial system deposit causes the highest variance in the return on asset in the $2^{\text {nd }}$ period leading to the ratio of bank credit to total deposit contributing highest in the $3^{\text {rd }}$ period consequently this large bank credit turns bad leading to large contribution of NPL in the $4^{\text {th }}$ to the $\mathrm{IO}^{\text {th }}$ period.

\section{Findings}

Deposit money bank with an ROA of $2.49 \%$ implies how profitable a deposit money bank is relative to its total assets. This shows that only $2.49 \%$ of the total asset of the Deposit Money banks is profitable therefore this low ROA shows that deposit Money Banks is not making enough income from the use of its assets. Hence deposit money bank can achieve a high ROA either by boosting its profit margin or, more efficiently, by using its assets to increase sales.

$14 \%$ of the total loan in deposit Money banks turn bad and becomes non-performing as indicated in the result of the descriptive statistics. The rationale for this high NPL cannot be far from the existence of high-interest rate, Low GDP, Poor credit appraisal, Inflation, unemployment and improper lending disbursement to agriculture sector within the Deposit money banks.

However, the study confirms the presence of long run relationship among Non-Performing Loan and the performance of Deposit Money Bank in Nigeria and affirms that only Non-Performing Loan has significant effect on Bank Performance in the Long run and the Short run as well although the speed of adjustment of the explanatory variables are significant hence the speed of adjustment towards long-run equilibrium is very high, that is, there is 177 percent increase over the previous year.

Nonetheless, Return on asset respond to Non-Performing Loan although the period and the response is relatively uniform as indicated by the impulse response function while the variance decomposition of the study shows that total financial system deposit causes the highest variance in the return on asset in the $2^{\text {nd }}$ period leading to the ratio of bank credit to total deposit contributing highest in the $3^{\text {rd }}$ period consequently this large bank credit turns bad leading to large contribution of NPL in the $4^{\text {th }}$ to the $10^{\text {th }}$ period. 


\section{Conclusion}

The study concluded that persistence increase in Non-performing loans results in poor Performance of Deposit Money Banks in Nigeria. Also, Non-Performing Loan reduces deposit money banks return on asset. The study therefore recommends that deposit money banks should employ competent risk managers that always use their skills to reduce the incident of nonperforming loans in the Nigerian deposit money banks. The study also recommends that deposit money banks in Nigeria should always monitor the end-use of funds given to their customers in order to curb the incident of fund diversion which may result in non-performing loan.

\section{References}

Abiola, I. \& Olausi, A. S. (20I4). The Impact of Credit Risk Management on the Commercial Banks Performance in Nigeria. International Journal of Management and Sustainability, 3(5), 295-306.

Ajayi, L. B. \& Ajayi, F. I. (2017). Effects of Credit Risk Management on Performance of Deposit Money Banks in Nigeria. International Journal of Research in Management \& Business Studies, 4(3), 50-55.

Bofondi, M. \& Ropele, T. (20II). Macroeconomic Determinants of Bad Loans: Evidence from Italian Conference, INEAG, Samos.

Ekanayake, E.M. N.N. \& Azeez A.A. (2015). Determinants of Non- Performing Loans in Licensed Commercial Banks: Evidence from Sri Lank. Asian Economic and Financial Review. 5(6), 868-882

Hamisu, S.K. (20II). Credit Risk and the Performance of Nigerian Banks, Department of Accounting, Ahmadu Bello University, Zaria, Nigeria.

Iwedi, M. \& Onuegbu, O. (20I4). Credit Risk and Performance of Selected Deposits Money Banks in Nigeria: An Empirical Investigation. European Journal of Humanities and Social Sciences, 3I(I), I684-I694.

Kolapo, T. F., Ayeni, R. K. \& Oke, M. O. (2012).Credit Risk and Commercial Banks' Performance in Nigeria: A Panel Model Approach. Australian Journal of Business and Management Research, 2(2), 3I-38.

Muhammad, F., Ammara S., Abrar, H.C, \& Fareeha, K. (2012). Economic Determinants of Non- Performing Loans: Perception of Pakistan Bankers. European Journal of Business and Management. 4(2), 20-29.

Salas,V. \& Sanrina, K (2006) Credit risk in two international setting : Spainish commercial and savings Bank. Journal of finance services Research, 22(3), 203-224.

Saba, I. Kouser, R. \& Azeem, M. (2012). Determinants of Non-Performing Loans: Case of US Banking Sector, International Journal of Banking and Finance, 4(4), 479-488.

Sinkey, H., \& Greenwalt J. (1990). Determinant of non-performing loans in Guyana-Research Gate.

Warue, B. N. (2013). The effects of bank and macroeconomic factors on nonperforming loans in commercial banks in Kenya: a comparative panel data analysis. Advances in Management and Applied Economics, 3(2), I35-I64.

\begin{tabular}{|c|c|c|c|c|c|}
\hline Year & LnNPL & $\ln B C I R$ & LnBCD & $\ln \mathrm{ROA}$ & $\ln \mathrm{TDP}$ \\
\hline 1986 & I.3II754 & I.8590I & I.890086 & 0.372822 & I.352954 \\
\hline I987 & I.334454 & $\mathrm{I} .86437 \mathrm{I}$ & I.9034I6 & 0.370515 & I. 235528 \\
\hline 1988 & I.334454 & I.869667 & I.859978 & 0.368194 & I.248709 \\
\hline I989 & 0.968483 & I.874899 & 1.86976 & 0.365862 & 1.135769 \\
\hline 1990 & 0.977724 & 1.880068 & I.848497 & 0.363516 & 0.812245 \\
\hline I99I & 0.856729 & I.745777 & I.786893 & 0.361158 & 0.871573 \\
\hline 1992 & I.57II26 & I.78604I & I.863025 & 0.358787 & 0.895423 \\
\hline 1993 & I.304059 & I.765I47 & I.88553I & 0.356403 & $0.96473 \mathrm{I}$ \\
\hline I994 & 0.761176 & I.774955 & $\mathrm{I} .87737 \mathrm{I}$ & 0.354006 & 0.930949 \\
\hline 1995 & 0.569374 & I.745777 & I.97I46I & 0.351596 & 0.826075 \\
\hline 1996 & 0.5302 & 1.83512 & 2.016114 & 0.349172 & 0.783189 \\
\hline 1997 & 0.326336 & I.825296 & 2.028449 & $0.2227 \mathrm{I} 6$ & $0.8 \mathrm{I} 358 \mathrm{I}$ \\
\hline 1998 & I.287802 & I.745777 & 2.026656 & 0.522444 & 0.843855 \\
\hline 1999 & $\mathrm{I} .40824$ & $\mathrm{I} .78604 \mathrm{I}$ & 1.97635 & 0.164353 & 0.9154 \\
\hline 2000 & I.354I08 & I.765I47 & I.915769 & 0.457882 & $0.96047 \mathrm{I}$ \\
\hline
\end{tabular}




\begin{tabular}{|c|c|c|c|c|c|}
\hline 2001 & I.294466 & 1.774955 & I.9II584 & 0.614897 & I.03583 \\
\hline 2002 & $\mathrm{I} .3304 \mathrm{I} 4$ & 1.767823 & I.9I4343 & 0.5302 & 0.984077 \\
\hline 2003 & I.3II754 & I.836007 & 1.92557 & $0.40 \mathrm{I} 40 \mathrm{I}$ & 0.974972 \\
\hline 2004 & $\mathrm{I} .334454$ & I.848189 & 1.956313 & 0.374748 & 0.932981 \\
\hline 2005 & I.334454 & 1.815777 & 1.971137 & 0.392697 & 0.940018 \\
\hline 2006 & 0.968483 & I.832253 & 1.95564 & $0.403 \mathrm{I} 2 \mathrm{I}$ & 0.942008 \\
\hline 2007 & 0.977724 & 1.790567 & I.9789II & 0.567026 & 1.082785 \\
\hline 2008 & 0.856729 & I.76II0I & 2.009366 & 0.521138 & $1.227 \mathrm{II} 5$ \\
\hline 2009 & I.57II26 & I.910464 & 2.016657 & 0.581153 & I. 287802 \\
\hline 2010 & I.304059 & I.85685 & I.977449 & 0.528917 & I. 243534 \\
\hline $20 \mathrm{II}$ & 0.761176 & I.842983 & I.8876I7 & -1.04576 & I.228I 44 \\
\hline 2012 & 0.569374 & I.791059 & I.82I382 & 0.511883 & I.240799 \\
\hline 2013 & 0.5302 & I.807535 & I.809358 & 0.361728 & I.254064 \\
\hline 2014 & 0.471292 & 1.795254 & 1.857332 & 0.367356 & 1.253096 \\
\hline 2015 & 0.686636 & $\mathrm{I} .83420 \mathrm{I}$ & $\mathrm{I} .8997 \mathrm{II}$ & 0.230449 & 1.247728 \\
\hline 2016 & I.I07888 & 1.836546 & 1.928908 & $0.26007 \mathrm{I}$ & 1.237292 \\
\hline 2017 & I.I70555 & I.838879 & I.886247 & 0.336932 & I.248219 \\
\hline
\end{tabular}

\section{Copyrights}

Copyright for this article is retained by the author(s), with first publication rights granted to the journal. This is an open-access article distributed under the terms and conditions of the Creative Commons Attribution license (http://creativecommons.org/licenses/by/4.0/). 